\title{
HUBUNGAN PEKERJAAN DENGAN KUALITAS STIMULASI IBU PADA ANAK GEMUK USIA 2-5 TAHUN
}

(The Reraltion of Work to The Quality of Maternal Stimulation in Obese Children Aged 2 to 5 Years)

\author{
Wulandari \\ Dosen Program Studi D3 Kebidanan Uiversitas Muhammadiyah Banjarmasin \\ Wulandari.f4@gmail.com
}

\begin{abstract}
ABSTRAK
Stimulasi merupakan aspek kebutuhan dasar manusia. Anak gemuk memiliki kondisi yang rentan terhadap masalah kesehatan fisik dan motorik. Pemberian stimulasi pada masa anak-anak awal dapat menunjang kemampuan anak. Pengasuhan dalam keluarga pada umumnya dilakukan oleh ibu sebagai pengasuh utama. Kondisi dan sifat dari pekerjaan ibu mempengaruhi kualitas pengasuhan anak. Tujuan: Penelitian ini bertujuan untuk mengetahui karakteristik orang tua dengan kualitas stimulasi pada anak gemuk usia 2-5 tahun. Metode: Jenis penelitian observasional dengan desain cross sectional. Sampel penelitian sebanyak 160 anak gemuk usia 2-5 tahun di wialayah kerja Puskesmas Kalasan. Hasil: Pekerjaan anak berhubungan secara signifikan dengan kualitas stimulasi $(p=0.028)$. Kekuatan hubungan lemah dan arah hubungan positif $(C=0.174)$. Kesimpulan: ibu rumah tangga memiliki kualitas stimulasi yang lebih baik dibandingkan dengan ibu bekerja.
\end{abstract}

Kata Kunci : $\quad$ pekerjaan, stimulasi, anak gemuk 2-5 tahun

\begin{abstract}
Stimulation is an aspect of basic human needs. Obese children have conditions that are prone to physical and motor health problems. Provision of stimulation during early childhood can support the ability of children. Care in the family is generally carried out by the mother as the primary caregiver. The conditions and nature of mother's work affect the quality of childcare. This study aims to determine the characteristics of parents with quality stimulation in obese children aged 2-5 years. This was an observational study with a cross sectional design. The research sample of 160 obese children aged 2-5 years in the Kalasan Health Center work area. Children's work was significantly related to the quality of stimulation $(p=0.028)$. The strength of the relationship is weak and the direction of the relationship is positive $(C=0.174)$. Housewives have better stimulation quality compared to working mothers.
\end{abstract}

Keywords: occupation, stimulation, fat children 2-5 years

\section{PENDAHULUAN}

Hubungan ikatan antara ibu dan anak yang baik merupakan salah satu syarat penting dalam perkembangan sosial emosional anak. Perkembangan sosial emosional anak tergantung dari kualitas stimulasi orang tua dan kunci keberhasilan stimulasi tergantung dari kemampuan dan banyaknya kesempatan orang tua dalam memberikan stimulasi kepada anakanaknya.

Kemampuan anak dalam menerima stimulasi akan lebih cepat saat berinteraksi dengan ibu. Sentuhan dan pelukan serta kebersanaan dengan anak merupakan modal utama dalam pemberian stimulasi ${ }^{1)}$ Kemampuan ibu melakukan stimulasi dipengaruhi oleh faktor usia, pendidikan, kepribadian dan sikap ibu. 
Kondisi saat ini memperlihatkan semakin banyak wanita pekerja, sehingga memungkinkan semakin banyak keluarga yang menyerahkan pengasuhan anak pada pembantu yang tingkat pendidikannya lebih rendah dari ibunya sendiri, pendidikan sepenuhnya diserahkan ke sekolah karena orang tua yang sibuk bekerja. Hal ini menyebabkan pembelajaran yang dilakukan oleh keluarga tidak berjalan secara optimal.

\section{METODE PENELITIAN}

Penelitian ini merupakan penelitian analitik observasional dengan rancangan cross sectional. Sampel penelitian sebanyak 160 anak gemuk usia 2-5 tahun di wialayah kerja Puskesmas Kalasan. Penelitian dilakukan dengan cara melakukan penilaian kualitas stimulasi ibu dengan infant-toddler HOME Inventory dan early children HOME Inventory.

Variabel Independen dalam penelitian ini terdiri dari umur ibu dan pekerjaan. Variabel Dependen dalam penelitian ini adalah stimulasi. Analisis bivariat dalam penelitian ini menggunakan uji Spearman Rank ( $\rho)$ untuk variabel berskala ordinal-ordinal seperti analisis hubungan pekerjaan dan stimulasi ${ }^{2}$.

Penelitian ini telah melalui proses uji kelayakan oleh Lembaga Pengembangan Penelitian dan Pengabdian Masyarakat (LP3M) Universitas 'Aisyiyah Yogyakarta. Responden telah diberikan informasi mengenai tujuan penelitian, prosedur pelaksanaan, manfaat penelitian dan kerahasiaan responden dan menyatakan kesediaan sebagai responden. Peneliti menjamin kerahasiaan informasi responden dengan mencantumkan kode untuk nama responden pada lembar penelitian. Penelitian ini tidak memiliki risiko yang membahayakan dan merugikan bagi responden. Penelitian ini memberikan manfaat berupa informasi tentang perkembangan serta bentuk stimulasi dan gaya pengasuhan yang tepat untuk anak. Penelitian ini dilakukan dengan memenuhi prinsip keadilan (tidak membedakan perlakuan antar responden), manfaat dan menghormati orang lain.

\section{HASIL DAN PEMBAHASAN}

\section{Karakteristik Responden}

Tabel 1 Distribusi frekuensi karakteristik ibu

\begin{tabular}{|c|c|c|c|}
\hline Karakteristik & & $\mathrm{n}$ & $\%$ \\
\hline $\begin{array}{l}\text { Karakteristik ibu } \\
\text { Umur ibu }\end{array}$ & & & \\
\hline Dewasa awal (21-40 tahun) & & 105 & 65.6 \\
\hline $\begin{array}{l}\text { Dewasa madya (41-60 tahun) } \\
\text { Pekerjaan ibu }\end{array}$ & & 55 & 34.4 \\
\hline $\begin{array}{l}\text { Bekerja (pedagang, jasa/ } \\
\text { pegawai swasta, PNS) }\end{array}$ & & 70 & 43.8 \\
\hline Ibu rumah tangga & & 90 & 56.2 \\
\hline
\end{tabular}

Karakteristik ibu di wilayah kerja puskesmas Kalasan seperti ditampilkan pada tabel 1 yaitu mayoritas ibu berada pada rentang usia dewasa awal.

Umur merupakan indikator kedewasaan seseorang ${ }^{3)}$ semakin bertambah umur semakin bertambah pengetahuan dan pengalaman yang dimiliki mengenai perilaku yang sesuai untuk mendidik anak ${ }^{4)}$.

Gunarsa menyebutkan bahwa umur dewasa awal dan dewasa madya memiliki risiko untuk terjadinya stress. Orang tua rentan terhadap emosi negatif seperti depresi, lekas marah, cenderung berperilaku kurang peka dan lebih keras dari orang tua lainnya ${ }^{4}$. 
Tabel 1 menunjukkan bahwa sebagian besar ibu adalah ibu rumah tangga sehingga orang tua dan anak memiliki banyak kesempatan untuk berinteraksi.

Kebersamaan orang tua, terutama ibu dan anak dapat meningkatkan interaksi ibu dan anak. Gaya yang digunakan orang tua saat berinteraksi, mendisiplinkan serta melakukan pengasuhan bersama memperlihatkan kualitas pengasuhan yang diberikan ${ }^{5}$. Adanya interaksi dengan manusia lain merupakan suatu hal yang sangat penting bagi seorang anak. kontak mata, senyuman, memberikan kesempatan pada anak untuk berkomunikasi lebih lanjut, adanya pertukaran makna dalam komunikasi, adanya keterlibatan orang tua atau pengasuh akan membantu anak dalam mengembangkan dunianya untuk berhubungan dengan orang lain $^{6)}$ 7) 8).

Ibu yang bekerja di luar rumah seringkali mempercayakan pengasuhan kepada nenek, keluarga dekat lain atau pembantu (babysitter). Anak-anak akan mendapatkan stimulasi yang berbeda dan gaya pengasuhan yang berbeda pula.

\section{Stimulasi orang tua}

Tabel 2 Ditribusi frekuensi berdasarkan kualitas stimulasi orang tua

\begin{tabular}{cccc}
\hline Variabel & Kategori & $\mathrm{n}$ & $\%$ \\
\hline Stimulasi & Kurang & 37 & 23.1 \\
& Baik & 123 & 76.9 \\
\hline
\end{tabular}

Tabel 2 menyajikan data hasil dari tiap variabel penelitian yaitu mayoritas ibu yang memiliki balita gemuk memberikan stimulasi yang baik $(76,9 \%)$ dan sebagian kecil ibu memiliki kualitas stimulasi yang kurang (23.1\%).
Stimulasi merupakan perangsangan yang datangnya dari lingkungan di luar individu anak dengan memberikan pengalaman pendidikan pada anak. stimulasi psikososial merupakan salah satu cara untuk memberikan pengalaman pendidikan bagi anak ${ }^{9)}$.

Sununingsih menjelaskan bahwa pemberian stimulasi berkaitan dengan pengasuhan yang dilakukan orang tua. adanya interaksi yang baik antara orang tua dan anak melalui kegiatan bermain, bernyanyi dan menggambar dapat memberikan rasa aman, nyaman dan pengalaman baik bagi anak sehingga anak menjadi responsif terhadap lingkungan ${ }^{9}$.

keterlibatan orang tua untuk menstimulasi anak merupakan faktor prediktor pencapaian anak dimasa depan ${ }^{10)}$.

Adanya pola interaksi yang baik antara orang tua dan anak akan menimbulkan balasan yang baik dari anak ${ }^{11)}$.

Hasil penelitian menunjukkan bahwa sekitar $23.1 \%$ ibu memiliki kualitas stimulasi yang kurang. Anak gemuk usia 24-35 bulan kurang diberikan stimulasi mengenai penerimaan terhadap perilaku anak. Sebagian besar ibu berteriak saat anak melakukan kesalahan, menunjukkan kekecewaan, memarahi anak dalam bentuk kata- kata dan isyarat serta membatasi/ melarang anak untuk bermain.

Regalado et $\mathrm{al}^{6}{ }^{6}$ menjelaskan bahwa perilaku kekerasan fisik, berteriak marah kepada anak menyebabkan hilangnya kepercayaan diri anak, menimbulkan rasa benci, dan menyebabkan masalah perkembangan di kehidupan anak 
mendatang. Perkembangan emosional anak terganggu, anak menjadi pasif dan tidak mandiri.

Hidayat ${ }^{12)}$ menerangkan bahwa penerimaan terhadap keberadaan anak merupakan satu bentuk ikatan kasih sayang yang dapat menumbuhkan basic trust (rasa percaya yang kuat) dalam diri anak. Rasa percaya diri inilah yang kemudian menjadikan anak memiliki motivasi yang tinggi untuk terus berkembang.

\section{Hubungan umur dan pekerjaan dengan stimulasi}

Tabel 2. Tabulasi silang umur dan pekerjaan ibu dengan stimulasi

\begin{tabular}{|c|c|c|c|c|c|c|c|c|}
\hline \multirow{3}{*}{ Variabel } & \multicolumn{4}{|c|}{ Stimulasi } & \multicolumn{2}{|c|}{ Total } & \multirow{3}{*}{$\begin{array}{c}p- \\
\text { valu } \\
e \\
\end{array}$} & \multirow{3}{*}{$\begin{array}{c}\text { Koefisien } \\
\text { korelasi } \\
(\rho)\end{array}$} \\
\hline & \multicolumn{2}{|c|}{ Kurang } & \multicolumn{2}{|c|}{ Baik } & \multirow[t]{2}{*}{$\mathrm{n}$} & \multirow[t]{2}{*}{$\%$} & & \\
\hline & $n$ & $\%$ & $\mathrm{n}$ & $\%$ & & & & \\
\hline \multicolumn{9}{|l|}{ Umur } \\
\hline $\begin{array}{l}\text { Dewasa } \\
\text { awal }\end{array}$ & 20 & 19 & 85 & 81 & 37 & 23.1 & \multirow[t]{2}{*}{$\begin{array}{l}0.0 \\
92\end{array}$} & \multirow[t]{2}{*}{$\begin{array}{l}\rho=(- \\
0.134)\end{array}$} \\
\hline $\begin{array}{l}\text { Dewasa } \\
\text { madya }\end{array}$ & 17 & $\begin{array}{l}30 . \\
9\end{array}$ & 38 & $\begin{array}{l}69 . \\
1\end{array}$ & 123 & 76.9 & & \\
\hline \multicolumn{9}{|l|}{ Pekerja } \\
\hline $\begin{array}{l}\text { an } \\
\text { Bekerja } \\
\text { Tidak } \\
\text { bekerja }\end{array}$ & $\begin{array}{l}22 \\
15\end{array}$ & $\begin{array}{l}31.4 \\
16 . \\
7\end{array}$ & $\begin{array}{l}48 \\
75\end{array}$ & $\begin{array}{l}68 \\
.6 \\
83 \\
.3\end{array}$ & 123 & $\begin{array}{l}23.1 \\
76.9\end{array}$ & $\begin{array}{l}0.0 \\
28\end{array}$ & $\begin{array}{c}\rho= \\
0.171\end{array}$ \\
\hline
\end{tabular}

Tabel 2 menjelaskan bahwa tidak terdapat hubungan antara umur ibu dan stimulasi $(p=0.092)$. Hurlock (1999) menjelaskan bahwa semakin dewasa umur seseorang semakin matang dalam mengasuh anak. Hasil penelitian tidak sejalan dengan pendapat tersebut.

Penelitian lain menjelaskan bahwa usia ibu yang muda dapat mempengaruhi sumber daya yang tersedia untuk anak. Hal ini menyebabkan kurangnya pengalaman dalam memberikan stimulasi pada anak ${ }^{4}$. Anak-anak dengan orang tua usia muda akan mendapatkan pengawasan yang lebih longgar karena dalam diri orang tua usia muda cenderung memiliki sifat toleransi yang tinggi dan memaklumi terhadap anak. Usia ibu muda juga dapat mempengaruhi sumber daya yang tersedia untuk anak ${ }^{4}$.

Selain itu, terdapat faktor lain yang berpengaruh dengan pemberian stimulasi pada anak. pendapatan orang tua dan stabilitas keluarga dapat mempengaruhi orang tua dalam hal pengasuhan anak6).

Pendapatan keluarga dari anak gemuk usia 25 tahun di wilayah kerja puskesmas Kalasan sebagian besar lebih dari 2,4 juta rupiah (45\%) dan keluarga yang memiliki pendapatan kurang dari 1,2 juta rupiah sebesar $26,3 \%$.

Hastuti menyatakan kestabilan keluarga diperlukan agar fungsi-fungsi keluarga dapat berjalan dengan baik. Keadaan ekonomi keluarga yang baik memberikan kesempatan yang luas kepada anak untuk mengembangkan berbagai macam kecakapan dan anak tentunya juga akan memperoleh pendidikan yang baik, serta alat permainan yang dapat menunjang stimulasi kepada anak9).

Tabel 2 menjelaskan bahwa terdapat hubungan yang signifikan antara status pekerjaan dan stimulasi $(p=0.028)$ dengan kekuatan hubungan sangat lemah $(\rho=0.171)$. Sejalan dengan penelitian Husaini dan Norman ${ }^{13)}$ salah satu faktor yang mempengaruhi kualitas stimulasi adalah keluarga.

Faktor keluarga yang sangat berperan dalam pelaksanaan stimulasi menurut Hastuti ${ }^{9)}$ adalah usia orang tua, jenis kelamin anak, tingkat pendidikan, besar keluarga, pekerjaan dan penghasilan. 
Seorang ibu berperan dalam menstrukturir lingkungan fisik anak (misalnya, dengan menggunakan benda-benda yang ada disekitarnya sebagai alat stimulasi) dan merespon terhadap kebutuhan-kebutuhan serta kesedihan atau ketakutan $a n a k^{12)}$. Hal ini ditunjang oleh penghasilan keluarga yang sebagian besar memiliki penghasilan rata-rata lebih dari 2,4 juta rupiah. Sehingga keluarga mampu memberikan alat stimulasi yang layak kepada anak-anak.

Caldwell dan Bradley ${ }^{14)}$ menjelaskan bahwa orang tua dan keluarga dapat memberikan stimulasi dalam bentuk pemberian pengalaman, dorongan belajar dan berbahasa, serta dorongan bagi kemampuan akademik anak.

\section{KESIMPULAN}

Ibu rumah tangga memberikan kesempatan besar dalam memberikan stimulasi yang baik kepada anak gemuk usia 2-5 tahun. Peneliti lain diharapkan dapat melakukan penelitian lebih lanjut tentang metode yang tepat untuk meningkatkan kualitas stimulasi yang dilakukan orang tua.

\section{PENGHARGAAN}

Penelitian ini dapat diselesaikan atas bantuan dari Universitas Muhammadiyah Banjarmasin yang telah mendanai kegiatan penelitian dan Kepala Puskesmas Kalasan bersama staf yang telah memfasilitasi terlaksananya penelitian ini.

\section{DAFTAR PUSTAKA}

Zahro, Aida Aisyatuz. (2009). Hubungan tingkat pengetahuan ibu tentang stimulasi verbal dengan perilaku membacakan cerita pada anak di Dusun Petet Desa Tuntang
Kecamatan Tuntang Kabupaten Semarang. KTI. Universitas Sebelas Maret.

Sasroamoro, Sudigdo dan Ismael, Sofyan. (2014). Dasar-dasar Metodelogi Penelitian Klinis. Edisi ke-5. Jakarta: Sagung Seto.

Hurlock (1999). Psikologi Perkembangan. Ed ke5. Jakarta: Erlangga

Blachman, D. R., \& Lukacs, S. (2009). America's Children: Key National Indicators of WellBeing. Annals of Epidemiology, 19(9), 667668.

Soetjiningsih dan Ranuh, G. (2012).Tumbuh Kembang Anak. Jakarta: EGC. Hal 14-71.

Santrock, John W. (2011). Life Span Development. 13th editions. New York: McGraw-Hill.

Blair, Clancy \& Diamond, A. (2008). Biological Process in Prevention and Intervention: The Promotion of Self-Regulation as Means of Preventing Scoll Failure. Development and Psychopathology. Vol. 20: h. 899-911.

Yulita, R. (2014). Hubungan Pola Asuh Orang Tua terhadap Perkembangan Anak BAlita di Posyandu Sakura Ciputat Timur. Skripsi. Fakultas IImu Keperawatan dan IImu Kesehatan Universitas Negeri Syarif Hidayatullah Jakarta.

Novita, D. (2013) HUbungan Stimulasi Psikosoial di Rumah dan Proses Pembelajaran dengan Kecerdasan Majemuk Anak Taman Kanak-kanak di Kecamatan Pamulang Kota Tangerang. Tesis. Departemen IImu Keluarga dan Perkembangan Anak. Institut Pertanian Bogor.

Pradipta, G. A. (2014). Keterlibatan orang tua dalam proses mengembangkan literasi dini pada anak usia paud di Surabaya. Journal Universitas Airlangga, 3(1), 1-2.

Gayatri. (2008). Pengaruh stimulasi psikososial, perkembangan kognitif, dan perkembangan sosial emosi terhadap perkembangan bahasa anak usia prasekolah di Kabupaten Bogor. [Skripsi] Bogor. Fakultas Pertanian. Institut Pertanian Bogor.

Triadi, D. (2009). Pengaruh terapi kelompok terapeutik terhadap kemampuan keluarga dalam memberikan stimulasi perkembangan dini usia kanak-kanak di Kelurahan Bubulak Kota Bogor Tahun 2009. Tesis. Fakultas IImu Keperawatan Universitas Indonesia. Depok. 
Bornstein L \& Bornstein H. ( 2014). Parenting Styles and Child Social Development. Parenting skill. Encyclopedia on early childhood Development. 3rd ed. University of Pennsylvania, USA: National Institute of Child Health and Human Development.
Hastuti D, Suprihatin, Guhardja. (2011).Kualitas Lingkungan Pengasuhan dan Perkembangan Sosial Emosi Anak Usia Balita di Daerah rawan pangan, Jur. IIm. Kel \& Kons.;4(1):57-65 